\title{
Promoting Effective Managerial Communication on Banking Sector in Kathmandu Valley: Cross Sectional Analysis
}

\author{
Udaya Raj Paudel ${ }^{1}$, Legina Tamrakar ${ }^{2}$, Niranjan Devkota ${ }^{3}$, Sashi Rana Magar ${ }^{4}$ and Seeprata Parajuli ${ }^{5}$
}

${ }^{1}$ Quest International College, Pokhara University, Nepal, https://orcid.org/0000-0002-5234-5081 email: udayapaudel7@gmail.com

${ }^{2}$ Quest International College, Pokhara

University,

email: tamrakarlegina@gmail.com

${ }^{3}$ Quest International College, Pokhara University, https://orcid.org/0000-0001-9989-0397, email: niranjandevkota@gmail.com

${ }^{4}$ Quest International College, Pokhara University, email: sashi.ranamagar@gmail.com

${ }^{5}$ Quest International College, Pokhara University, https://orcid.org/0000-0003-4466-4784 email:pseeprata@gmail.com

Received on : March 15, 2021

Revised on: Oct 10, 2021

Accepted on: Dec 10, 2021

\section{Cite this paper}

Poudel, U. R., Tamrakar, L., Devkota, N., Magar, S. R., and Parajuli, S. (2021). Promoting Effective Managerial Communication on Banking Sector in Kathmandu Valley: Cross Sectional Analysis. International Research Journal of Management Science, vol.6(1), pp. 110-127

\begin{abstract}
Purpose: Efficient managerial level is crucial to any organization for well function and betterment of the organization. Likewise, managerial communication is essential to build good relationship among managers to their subordinates. Proper communication in banks further helps to assist employees, creating sense of mutual respect and favorable working environment. This study aims to identify strategy for promoting effective managerial communication in banking sector in Kathmandu valley.
\end{abstract}

Research Design/ Methodology: A descriptive cross-sectional research design has been applied for this study where 405 managers (383 branch managers and 22 operating managers) of commercial Banks in Kathmandu Valley were taken as a sample using structured questionnaire survey using KOBO Toolbox. This study develops and uses Managerial communication index to identify the communication skills of managers in banking communication and decision making.

Findings: Managerial Communication Index value shows that managers of banking sector in Kathmandu valley are highly aware of managerial communication in terms of identity factors, negotiation and adaptation, and decision making. Brining clarity while giving speech or talking $(69.13 \%)$, regularly gathering feedback for improvement (16.54\%) and changing behavior and perception when necessary (12.34\%) are some of the management strategies identified for promoting effective managerial communication.

Conclusion: Hence, the study concludes that bank managers must properly disseminate the information to its stakeholders which will help to convey message effectively leading clarity in the work and enhancing productivity.

Recommendations: The paper recommends that there should be inclusive climate in the workplace. Further, policies supporting communication should be forwarded.

Originality: This article is original and there is no potential conflict of interest with respect to research and publication of this article.

Keywords: Banking Communication, Commercial Banks, Managerial Communication Index, Descriptive Analysis, Kathmandu 


\section{Background}

Managerial communication is a global phenomenon as business cannot sustain without a strong internal and external communication (Roy, 2018); it is an indispensable tool for organizational development as well as crucial instrument of social interactions and a medium by which all the relationships are established and maintained (Ekeowa, 2016). Communication is a crucial element for business success as it is the mainstream of organization's development (Nabi et al., 2017; Kurtuhuz et al., 2011; Ekeowa, 2016). A manager must have multitasking quality which keeps employees motivated, and helps take effective decisions which leads organization towards success (Kurtuhuz et al., 2011) and smart managers understand that the effective communication is essential for success of the business (Nabi et al., 2017; Kurtuhuz et al., 2011; Ekeowa, 2016). The basic process of management such as planning, organizing, leading and controlling cannot be performed without the effective communication system (Nabi et al., 2017). In an organization, decision making is not an easy task, it involves the process of identifying and choosing among the alternatives. Similarly, looking back at the past decisions and extracting lessons from the past experience would help in order to improve the decision-making process. Further, when problems arise channel like decentralized communication are the most suitable methods in order to facilitate better information flow and decision making (Al Nahyan et al., 2019). Paudel et al. (2018) stated that effective communication is inevitable aspect to make adjustments in any organization. Such adjustment can be for negotiation, public relation and many other official communication links and channels.

In Nepalese context, managers indeed realize that the decision making in an effective way in organization leads to accomplishment of defined objectives and goals (Prasad, 2002). However, most of the Nepalese managers tend to identify very less alternatives for solving the problem. Although in Nepal managerial communication has been a concern for financial institutions and communication has been gradually growing in commercial banks of Nepal, most of the Nepalese managers still face some problems in the organization while making decisions (Rijal, 2007). Nepalese banks have been using information technology as a communication medium where banks can provide knowledge of information technology to users for effective decision making (Sapkota et al., 2018). However, it is necessary to examine more carefully regarding the role of communication in participative decision making. According to Shrestha et al. (2019) effective communication in banks promotes cooperation, increases efficiency, productivity, and job satisfaction. Further, it also increases external and internal communication between employees and managers. The study conducted by Parajuli et al. (2020) revealed that there is very strong positive relation between banking communication and perceived customer satisfaction thus, banks must adopt proper strategies to manage banking communication in Nepal.

Managerial communication is important issue but still in Nepalese banking context there are several questions which is not yet answered especially in terms of managerial communication (Paudel et al., 2020; Parajuli et al., 2020). In accordance with managerial communication in decision making, this study targets to provide recommendation relative to the following research questions: Why is managerial communication essential? What are the challenges of managerial communication? What are the barriers to managerial communication? What are the management strategies for promoting effective managerial communication? To identify the mentioned questions, present study aims to identify strategy for promoting effective managerial communication on banking sector in Kathmandu valley. This study assists banks of Nepal in improving their managerial communication skills and assist policy makers in developing new policies keeping managerial communication into consideration. 
This study is further divided into five sections. Section 2 reviews the relevant literature; section 3 covers the methodology; section 4 presents the result and discussion; and finally, section 5 concludes the study.

\section{Literature Review}

Knowledge, information and skills in the present digital economy are very important whereas the manager's individual skills many times may represent a competitive advantage over other organizations (Mesaros et al., 2016). Similarly, Genc (2017) entails that the communication is the exchange of thoughts, ideas, and feelings by sender to receiver through verbal or nonverbal medium and this transfer adds special significance in business more in the service sector because the service providers work with people which is based on interaction. Mayfield (2016) has discussed about the motivational language theory which has been concerned with tools in all organizational levels can encourage better decision making as well as decision making of worker is mostly influenced by the leader communication as well as behavior. Similarly, Mesaros et al. (2016) described about the building information model that managers have more information to make accurate decisions and it also which helps to effectively work in project documentations. This model helps in communication to clarify the specific things in tasks, whereas is it a flexible platform. Likewise, Dane and Pratt (2007) explain that Rational decision making model has garnered the lion's share in managerial decision through using information processing system and model states that institution could be viewed as entire population's subset in decision making which is used by the experts.

More specifically, rather than concentrating only on national and organizations' work-life policies, top level management must pay more attention to the informal work communication. In order to capture the role of interactions more correctly, we must study actual dialogue between employees and managers (Hoeven et al., 2017). It was found that those with limited management experience can benefit significantly from a unique perspective on management challenges and from simulating aspects of communication and decision making in organization. In business curriculum, role-plays are promoted as a bonafide option to teach as and is considered a way to prepare participants for the real world (Mercado, 2000). Dasgupta et al. (2013) has observed that an assertive style of communication provides maximum support to the employees where perceived supervisory support at the workplace extends satisfaction of employees with communication of supervisor's self-esteem. As Paudel et al. (2020) recommended awaring customers about advanced tools used by banks, improving customer's service, reviewing banking policies, addressing customers' complaints. These recommendations should be considered and incorporated in managerial strategy of banks.

Further, Bel et al. (2018) has argued that the internal processes of the firm have significant affect in a firm's ability to implement change and the focus is on communication protocol, managerial style and their interaction. It is recommended that internal organizational structure will help in different performance of comparable firms. However, a Good managerial and digital competency of managers frames the competitive advantage of every organization. Therefore, developing managerial and digital skills is a difficult process. More specifically in Taiwan Mesaros et al. (2016) in the study shows how political ties influence firm's choice of key staff employment, information flow blockage and the potential conflicts of interest which is related with external political entities; however it is suggested that researchers must consider corporate culture as well as management philosophy conflict as one of the important elements in their internal communication system. 
Managers must utilize their political and business ties organizational capability development, because excessive investments do not always stimulate to obtain a desirable performance outcome (Chung et al., 2016). Moreover, Genc (2017) has discussed that communication plays a vital role in sustainable plan. In order to develop sustainability, it is important for people to express themselves by using right mode of communication. Thus, to establish effective communication, the manager has to channel the receiver what they mean to communicate in a precise, simple and direct way. Also, Shrestha et al. (2020) revealed that only $37 \%$ employees of banks are adequately aware about banking communication thus, banks should implement effective strategy which could enhance employees' awareness on banking communication in context of Nepal.

\section{Methods}

Research Design, Study Area, Population, Sample and Data

This study is based on cross-sectional descriptive research design. Kathmandu valley is taken as the study area. Being the capital city of Nepal, banks have its head office located in Kathmandu valley itself (Shrestha et al., 2021). The latitude of Kathmandu valley is $27^{\circ} 32^{\prime \prime} 13^{\prime \prime}$ and $27^{\circ} 49^{\prime \prime} 10^{\prime \prime}$ north and longitudes is $85^{\circ} 11^{\prime \prime} 31^{\prime \prime}$ and $85^{\circ} 31^{\prime \prime} 38^{\prime \prime}$ east (Figure 1) which covers three districts: Kathmandu, Bhaktapur and Lalitpur which covers area of 899 square kilometers (Mohanty, 1970; Ishtiaque et al., 2017; Pant \& Dongol, 2009; Adhikari et al., 2021). People from different parts of the country have been migrated to its capital; maximum numbers of branch offices are present in the valley as well. According to NRB (2018) among the 27 commercial banks of Nepal all of them have its headquarters in Kathmandu valley (Shrestha et al., 2021). All the managers who are responsible for decision making in commercial bank in Kathmandu valley are considered as population for the study.

Figure 1: Study Area

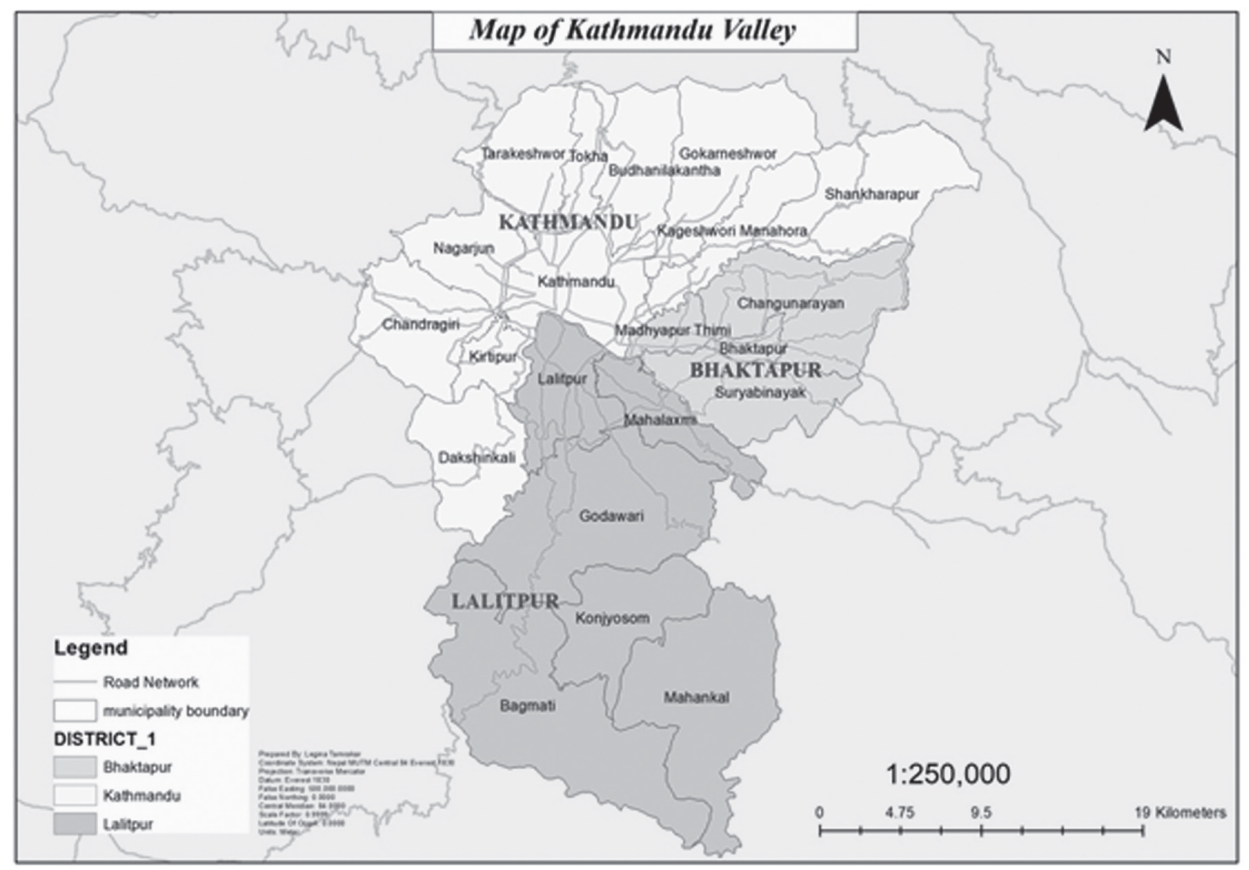


To determine the sample size of the study following formula was used: $n=z^{2} p q / 1^{2}$ (Panth \& Kafle, 2018; Adhikari et al., 2021). Where $n 0=$ sample size required for study, standard tabulated value for $5 \%$ level of significance $(\mathrm{z})=1.96, \mathrm{p}=$ Prevalence or proportion of an event $50 \%=0.5$. So, $\mathrm{P}=0.5, \mathrm{q}=1-\mathrm{p},=0.5$, Allowable error that can be tolerated $(e)=5 \%$. Thus, sample size taken for study was 405 . As the study is carried out on basis of descriptive research design, the research is based on survey questionnaire. A structure questionnaire has been arranged to conduct survey on effective managerial communication on banking sector for data collection. Pre-resting of the questionnaire was conducted among 20 managerial staffs of the banks and their feedback was taken. Final questionnaire was developed as per the incorporation of all the feedbacks received during pre-testing. The final questionnaire was maintained in KOBO Toolbox for data collection. Finally total 405 Banking staffs at managerial positions ( 383 branch managers and 22 operating managers) in banks of Kathmandu valley were undertaken for the study. For data analysis, managerial communication index was developed.

\section{Results and Discussion}

\subsection{Socio- Demographic Characteristics of Respondents}

This section is concerned with the analysis of various socio demographic characteristics like age, gender, education level, work experience, income level and marital status of managers in banking sector in Kathmandu valley. Age is considered to be the most important factor for managerial communication in decision making. According to the study made by Chong (2013) The age of the managers varies between 29 and 54 years with an average age of 38.1 years (Table 1). Only five are female. Similarly, Vilkinas and Cartan (1997) in the study stated that the average age of the managers was 33.2 and $35 \%$ were female. In this study, there are total 405 respondents and maximum (91.4\%) number of respondents were from the age group 31 to 40 .

The study conducted among 405 managers (383 branch managers and 22 operating managers) in banks of Kathmandu valley included $80 \%$ male respondents and $20 \%$ female respondents. This clearly portrays that there are more male bank managers in Kathmandu valley. The study made by Dasgupta et al. (2013) concluded that there were very few female employees compared to male employees in the manufacturing organizations and accordingly the sample contained a lower representation of females. This study covered managers having education level starting from to bachelors and masters which unleashed that 61.97\% manager's holds master's degree. Dasgupta et al. (2013) in the study assumes that while female employees had studied more number of years in formal schools and colleges than that of male employees, on average, each male employee had received about two promotions compared to only one promotion per female employee during their job in the organization.

Working experience is one of the important aspects of respondent which can determine their knowledge regarding the organizational experience, here in this research banking communication, and they can give their response accurately. Likewise, majority (92.83\%) of bank managers of Kathmandu valley had work experience of 6-10 years. But it was also found that among the women managers they hold experience of 1-5 years. 
Table 1: Socio-Demographic Characteristics

\begin{tabular}{|c|c|c|}
\hline Title & Number & Percentage \\
\hline \multicolumn{3}{|l|}{ Age } \\
\hline Below 30 & 13 & 3.2 \\
\hline $31-40$ & 370 & 91.4 \\
\hline $41-50$ & 21 & 5.2 \\
\hline Above 50 & 1 & 0.2 \\
\hline \multicolumn{3}{|l|}{ Gender } \\
\hline Male & 324 & 80 \\
\hline Female & 81 & 20 \\
\hline \multicolumn{3}{|l|}{ Marital Status } \\
\hline Married & 385 & 95.06 \\
\hline Unmarried & 14 & 3.45 \\
\hline Divorced & 2 & 0.49 \\
\hline \multicolumn{3}{|l|}{ Education level } \\
\hline Bachelor's & 154 & 38.02 \\
\hline Master's & 251 & 61.97 \\
\hline \multicolumn{3}{|l|}{ Work Experience } \\
\hline Below 5 years & 17 & 4.19 \\
\hline $6-10$ years & 376 & 92.83 \\
\hline Above 10 years & 12 & 2.96 \\
\hline \multicolumn{3}{|l|}{ Income } \\
\hline Less than 50000 & 11 & 2.71 \\
\hline $50001-70000$ & 90 & 22.22 \\
\hline $70001-90000$ & 221 & 54.56 \\
\hline $90001-110000$ & 66 & 16.29 \\
\hline $110001-130000$ & 17 & 4.19 \\
\hline
\end{tabular}

Considering work experience of female managers, recently, with the increase in awareness about women empowerment, females have started stepping outside for contributing economically that may be the reason why majority of female have work experience in between one to five years. As facilities received by bank managers and their income are perceived to be fascinating it was revealed that $54.56 \%$ manager's 
income ranged between 70001- 90000. However 2.71\% managers had income less than 50000 and $4.19 \%$ had income between $110001-130000$. This study clearly portrays that most (95.06\%) of the managers in banking sector of Kathmandu valley are married that may directly or indirectly influence in managerial communication in decision making.

\subsection{Information on Managerial Communication}

This section of the study exposes different information provided by 383 branch managers and 22 operating managers regarding managerial communication in banking sector. It deals with what level of understanding managers have regarding communication and decision making as well as information provided by their respective bank is tried to be portrayed in this part of study.

Respondent's Communication Skills and Encountered Miscommunication: Various languages are used by managers while communicating with their employees and clients. While surveying with managers it was identified that Nepali, English were major language used in bank. Similarly, manager's communication skills were taken into consideration for the analysis where it was found only $0.24 \%$ of respondent their communication skill as excellent, $31.85 \%$ marked themselves as very good in communication skills, $41.23 \%$ rated themselves as good and $26.66 \%$ replied fair to rate their commutation skills. The analysis also illustrated that most of the managers prefer to rate good in their communication skills. Banks are greatest financial service providers where they need to communicate with employees, clients and customers of different nature in order to get their job done. While doing so managers might face various issues and problems. Wide range of customers or clients prevail in banks and every people hold different background and identity. In the study conducted it exposed that minimum respondents don't have problems with banking communication. But who responded they had encountered miscommunication in banks they had come across moderate level of problems while communicating. 39 respondents replied that they never had misunderstanding with banking staffs and $90.37 \%$ replied they had miscommunication with banking staffs, clients and customers up to certain extent. Some of the major encountered miscommunication faced by managers is incomplete information provided, clash in communication style, lack of cultural awareness, confusing emails, making assumption, poor listening skills, and the other person carrying the message, customer misreading the policy, customers not coordinating and cooperating and so on.

Communicating with Employees in the Organization for Decision Making: Nepalese managers indeed realize that the decision making in an effective way in the organization leads to accomplishment of defined objectives and goals (Prasad, 2002). Similarly, Pokhrel (2007) has mentioned that decision making is a routine work of almost every manager and the quality of decision making affects the organization's survival. Therefore, the study depicted that $36.04 \%$ managers always consult with employees in the organization for making decision, $58.02 \%$ frequently consult with employees, $3.20 \%$ respondents often consult with employees and $2.71 \%$ managers rarely consult or communicate with employees in the organization for making decision. Managers provided various reasons why banks might not have been 
consistent with the communication they were following earlier and some of the reasons assembled are banks have started neglecting their employees once they have made their decision, managers might have thought communicating information to employees are not their major priority. Some also responded that employees might be busy on their daily operation which led them to run out of time so they could not communicate properly. System failure could be another reason why proper communication is not successful.

Manager's Satisfaction Level of Communication in the Organization: Communication should reflect the aspirations of the people and communicators should have coordinal relationship with audience as communication has become the key element in the development and implementation of policies and programmers which aims at the well being of people everywhere (Pokhrel, 2007). It has observed that $41(10.12 \%)$ managers are satisfied from the banking communication within the organization. From overall respondents 164 respondents were seems to be satisfied on the other hand, 189 respondents were reported to be neutral. The result was also generated that 11 respondents were dissatisfied from the communication that takes place in their respective organization. According to study conducted by Ahmed (2009) it was disclosed that satisfaction level in commercial banks were moderate which means satisfaction level is neither high nor low which has similar result to present study which shows half of the respondents were satisfied with banking services that falls into neutral category. So, it can be said that current managers of banking sector of Kathmandu valley are neutral in satisfaction level regarding communication.

Effectiveness of Bank's Communication about New Schemes: Banks often bring out new schemes, offers in their service, facilities in order to attract and retain their customers and clients. While discussing with respondents about effectiveness of communication related to new schemes by their respective banks, $25 \%$ respondents replied that it is highly effective, followed by very effective (55\%), moderately effective (8\%) and less effective (11\%). On analysis made among the respondents who told their bank communicate about new schemes with them; highly effective level of communication resulting very effective was generated. Martovoy and Dos Santos (2012) in a study conducted in UK state that it is important to disseminate knowledge about new products and schemes. It supports in extensive and cross functional communication with customers and also makes communication method to increase ability of customers and bank to learn new ideas and phenomenon from the market but this study conducted in Nepal shows that banks moderately communicate about new schemes which just serve its purpose but is not that effective. So, as per the result generated it can be said that if banks start communicating regarding new schemes that would help bank to create good relationship with employees, clients and customers.

Expectation of Managers on Bank will Communicate in New Changes: While receiving any kind of services, managers hold certain expectations. Similarly, while acquiring service from banks as well customers hold certain expectation regarding various facilities. In the study conducted to know 
managerial communication in decision making, managers revealed their various expectations regarding communication system that would be helpful for them. Among various expectations led by managers $80 \%$ stated that they always expect bank to communicate in new changes, if banks provide proper information in time then that will benefit for them while communicating effectively and efficiently. Similarly, $14.56 \%$ urged that they usually expect bank to communicate in new changes if banking facilities are improved then communication pattern in banks can also be improved. Likewise, $5.18 \%$ replied that sometimes they expect bank to communicate in new changes. However, only $0.24 \%$ respondent had rarely expected that bank will communicate in new changes. Some managers also told that improvement in advertisement would help to facilitate advanced communication in banks on the other hand some felt there are various other factors that can aid advanced communication in banks.

\subsection{Determinants of Managerial Communication}

This section intends to identify the factors that affect understanding of managers regarding the communication and decision making in banks. Respondents were asked what the influence of communication on organizational result is. 319 respondents stated that communication influence on organizational level is extremely high, which was witnessed as highest response from the managers. While analyzing level of communication influencing on organizational result, 80 respondents answered that communication influences on organizational result at high level and 6 respondents stated neutral to the influence of communication on organizational result, which witnessed as lowest response from the managers. Therefore, $96.2 \%$ employees working in Nepalese commercial banks felt they have cooperative work environment and found that the banks co-operative where they were carrying their banking activities (Rijal, 2007). Related consequence was generated from this study as well which shows maximum respondents (319) felt communication has extremely high influence on organizational result. As the respondents view, various services are offered by banks where communication and decision making plays a vital role. 381 respondents think that communication influences decision making on overall organizational service is extremely high, whereas 22 respondent stated communication influence in Decision Making on Overall Organizational Service in high level, and 2 respondents answered as neutral. The analysis illustrated that communication in decision making has influence overall organizational service in extremely high level.

\subsection{Managerial Communication Index}

Managerial communication index of banking sector is presented in this section to show the communication skills of managers on banking communication and in decision making. The index has been analyzed in three parts such as Identity, negotiation and adaptation and third one is decision making. Based on their response managers have been segregated as highly aware, moderate and low aware. Table 2 shows managers' communication index. 
Table 2: Managerial Communication Index

\begin{tabular}{|c|c|c|c|c|}
\hline \multirow{2}{*}{ Dimensions } & \multicolumn{2}{|l|}{ Yes } & \multicolumn{2}{|l|}{ No } \\
\hline & Number & $\%$ & Number & $\%$ \\
\hline \multicolumn{5}{|l|}{ Identity } \\
\hline $\begin{array}{l}\text { I think cultural background of the manager affects her/his } \\
\text { identity. }\end{array}$ & 405 & 100 & 0 & 0 \\
\hline Language manager speaks affects her/his identity & 402 & 99.25 & 3 & 0.74 \\
\hline I think administering time impacts manager's identity & 405 & 100 & 0 & 0 \\
\hline Identities are formed during the socialization process & 405 & 100 & 0 & 0 \\
\hline $\begin{array}{l}\text { Identities are shaped in diverse ways in different cultural } \\
\text { context }\end{array}$ & 405 & 100 & 0 & 0 \\
\hline Identities are multiple, complex and dynamic & 405 & 100 & 0 & 0 \\
\hline Identities are formed or constructed during communication & 405 & 100 & 0 & 0 \\
\hline Identities are expressed verbally and non-verbally & 404 & 99.75 & 1 & 0.24 \\
\hline Identities are based on class, gender and age basis as well & 405 & 100 & 0 & 0 \\
\hline $\begin{array}{l}\text { Identities are formed by physical and mental ability of } \\
\text { manager }\end{array}$ & 405 & 100 & 0 & 0 \\
\hline $\begin{array}{l}\text { Identities are also based on region and religion of the } \\
\text { manager }\end{array}$ & 403 & 99.50 & 2 & 0.49 \\
\hline Knowledge and education level of manager impacts identity & 405 & 100 & 0 & 0 \\
\hline Tone and communication style of the manger affect identity & 405 & 100 & 0 & 0 \\
\hline I think appearance and grooming affect manager's identity & 405 & 100 & 0 & 0 \\
\hline $\begin{array}{l}\text { Managerial communication of manager determines her/his } \\
\text { identity }\end{array}$ & 404 & 99.75 & 1 & 0.24 \\
\hline \multicolumn{5}{|l|}{ Negotiation and Adaptation } \\
\hline I think sufficient time for adjustment affects negotiation & 399 & 98.51 & 6 & 1.48 \\
\hline I think gender affects in negotiation/adaptation & 402 & 99.25 & 3 & 0.74 \\
\hline I think cultural differences affect in negotiation & 403 & 99.50 & 2 & 0.49 \\
\hline Power allocated to manager affects in negotiation & 403 & 99.50 & 2 & 0.49 \\
\hline The personality of the manager affects in negotiation & 405 & 100 & 0 & 0 \\
\hline I think discrimination affects in negotiation & 405 & 100 & 0 & 0 \\
\hline Positive thinking of manager makes negotiation better & 404 & 99.75 & 1 & 0.24 \\
\hline The emotion of the manager affects in negotiation & 358 & 88.39 & 47 & 11.60 \\
\hline $\begin{array}{l}\text { Knowing the background of employees makes negotiation } \\
\text { better }\end{array}$ & 402 & 99.25 & 3 & 0.74 \\
\hline $\begin{array}{l}\text { The nature of compromise between two parties affects in } \\
\text { communication }\end{array}$ & 405 & 100 & 0 & 0 \\
\hline \multicolumn{5}{|l|}{ Decision Making } \\
\hline $\begin{array}{l}\text { I think level of language of the manager affects decision } \\
\text { making }\end{array}$ & 403 & 99.50 & 2 & 0.49 \\
\hline $\begin{array}{l}\text { I think communication tone, style and efficiency affect in } \\
\text { decision }\end{array}$ & 405 & 100 & 0 & 0 \\
\hline I think power and position of manager affect in decision & 372 & 91.85 & 33 & 8.14 \\
\hline I think economic class of manager affects in decision & 306 & 75.55 & 99 & 24.44 \\
\hline The cultural background of the manager affects in decision & 394 & 97.28 & 11 & 2.71 \\
\hline $\begin{array}{l}\text { Reflexive thinking of the manager makes manager easy to } \\
\text { decide }\end{array}$ & 405 & 100 & 0 & 0 \\
\hline $\begin{array}{l}\text { I think knowing the background of the employees affect in } \\
\text { decision }\end{array}$ & 231 & 57.03 & 174 & 42.96 \\
\hline I think fair representation does not exist in organization & 37 & 9.13 & 368 & 90.86 \\
\hline $\begin{array}{l}\text { Creating bad images of the employees takes place in } \\
\text { organization }\end{array}$ & 35 & 8.64 & 370 & 91.35 \\
\hline $\begin{array}{l}\text { I think communication of union of employees affects in } \\
\text { decision }\end{array}$ & 389 & 96.04 & 16 & 3.95 \\
\hline
\end{tabular}


In the awareness index part, respondents were asked fifteen different questions related to their identity factors to find out how many of them are aware and are not aware in terms of identity factors. We have taken Identity factors as an important index because identity plays vital role in communication. Identity determines manager's personality. The result mentioned in the table 2 shows that all 405 managers i.e. $100 \%$ of the respondents highly preferred managerial communication in identity factors. From the results we can say that almost all of the managers of banking sector in Kathmandu valley are highly aware about the identity factors.

Similarly, to identify managerial communication in terms of negotiation and adaptation respondents were asked whether they are aware of managerial communication in terms of negotiation and adaptation in the banking sector. Result revealed that out of 405 respondents, only 4 respondents (i.e. $0.98 \%$ ) are moderately aware and rest 401 (i.e. 99.01\%) of managers are highly aware of managerial communication in terms of negotiation and adaptation. From the results we can say that maximum respondents are highly aware of managerial communication in terms of negotiation and adaptation factors.

To understand managerial communication in terms of decision making respondents were asked whether they are aware or not regarding managerial communication in terms of decision making factors. The result revealed that out of 405,2 i.e. $0.49 \%$ of respondents were less aware, 233 i.e. $57.53 \%$ of the respondents were moderately aware and 170 i.e. $41.97 \%$ of respondents were highly aware of managerial communication in terms of decision making factors. From the results we can say that the maximum respondents are moderately aware of managerial communication in terms of decision making factors.

Figure 2: Overall Managerial Communication Index

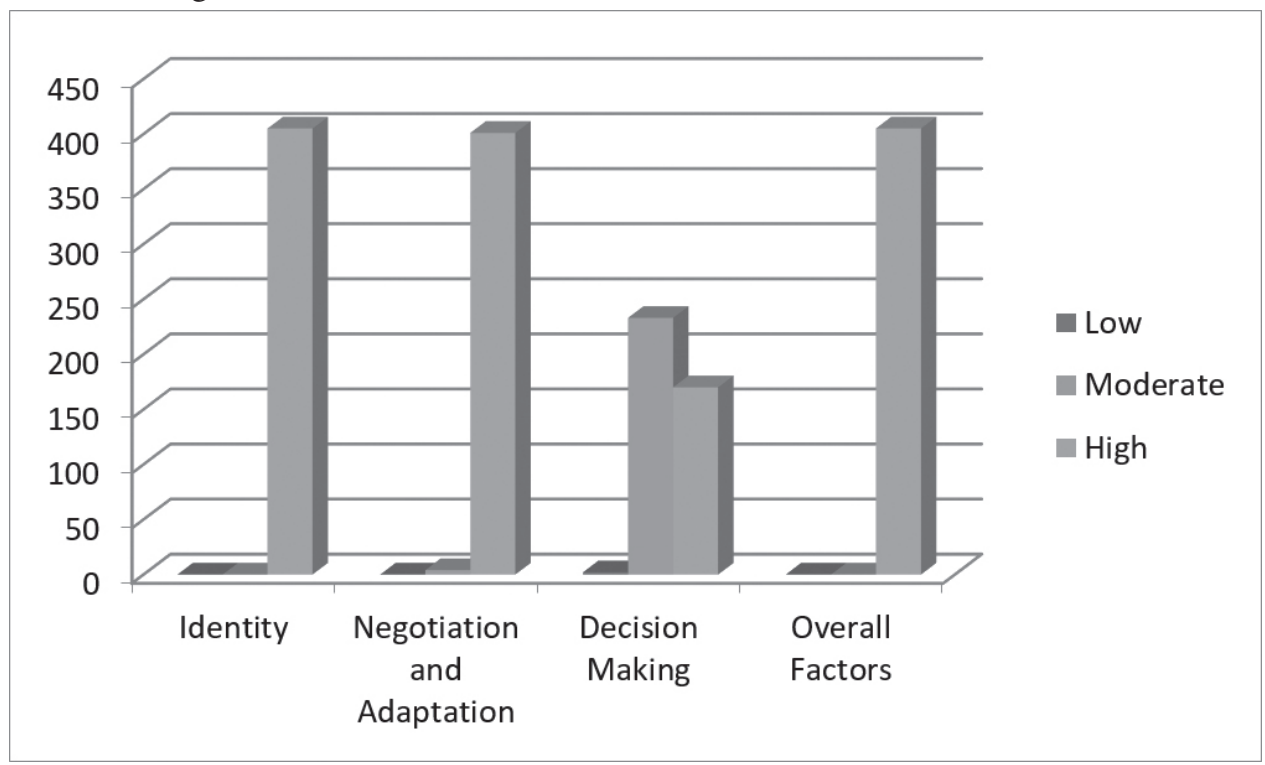

In Figure 2, out of 405 respondents we can clearly observe that only $0.45 \%$ of the respondents are less aware about the decision making factor and $0.98 \%$ in negotiation and adaptation, and $57.53 \%$ in decision making are moderately aware about the managerial communication. Maximum respondents are highly aware about the identity, negotiation and adaptation and decision making factors along with almost all 
of respondents in the overall factors of managerial communication in decision making. We can observe that there are altogether 405 , where $100 \%$ respondents are all highly aware in terms of managerial communication. Therefore from the results we can say that overall index depicts that managers of banking sector in Kathmandu valley are highly aware of managerial communication in terms of identity factors, negotiation and adaptation and decision making.

\subsection{Challenges of Managerial Communication}

Banks are said to be greatest financial service providers where they need to communicate with clients or customers of different nature in order to get their job done where managers might face various issues and problems. Wide range of people prevails in banks with different background and identity. The study exposed that most of the (57.77\%) managers have to face problems with banking communication up to certain extent (Table 3). Some managers come across having 3 to 4 times misunderstanding with staffs, clients and customers in the bank daily.

\begin{tabular}{|c|c|c|}
\hline Title & Number & Percentage \\
\hline Challenges faced by the Managers & 58 & 14.32 \\
\hline Yes & 42 & 10.37 \\
\hline \multicolumn{3}{|l|}{ No } \\
\hline Occurrence of Challenges & 341 & 84.19 \\
\hline Always & 4 & 0.98 \\
\hline Frequency & 3 & 0.74 \\
\hline Often & 54 & 13.33 \\
\hline Rarely & 3 & \\
\hline \multicolumn{3}{|l|}{ Sometimes } \\
\hline Level of faced due to Communication & 1 & 0.24 \\
\hline Extremely high & 25 & 6.17 \\
\hline High & 360 & 88.88 \\
\hline Moderate & 19 & 4.69 \\
\hline Low & 0 & 0 \\
\hline \multicolumn{3}{|l|}{ Extremely low } \\
\hline Communication Barriers & 137 & 33.82 \\
\hline Yes & 268 & 66.17 \\
\hline \multicolumn{3}{|l|}{ No } \\
\hline Main Responsible for Managerial Communication & 264 & 65.18 \\
\hline Branch Manager & 100 & 24.69 \\
\hline $\begin{array}{l}\text { Managerial Staff } \\
\text { Head Office }\end{array}$ & 41 & 10.12 \\
\hline
\end{tabular}

Managers feel that the challenges of managerial communication arise due to the language barriers. It is said that communication is integral part for banks effective performance, managers illustrated that 
managerial challenges rises due to cross cultural communication and managing diversity is one of the great challenge in decision making. They also expressed that one of the challenges of managerial communication is due to lack of mutual respect, as well as exercising strong leadership is one of the challenge that plays vital role in managerial communication decision making. Managers thinks dealing with aggressive clients is one of the challenges they face in the organization, therefore managers claim that managing financial stress in the organization is challenge for them and they also perceive that building an effective team is challenge for managerial communication while decision making.

The study revealed that maximum (84.19\%) managers perceive that communication challenges arise sometimes according to situation in banks. Though challenges arise it was observed that it was managed within few days. According to study conducted by Rijal (2007) it was disclosed that satisfaction level in banks were moderate which means satisfaction level is neither high nor low which have similar result to present study many of them were in problems with banking services that falls into neutral category. So, it can be said that current managers of banking sector of Kathmandu valley are facing challenges in moderate level.

\subsection{Management Strategy for Promoting Effective Managerial Communication}

Communication plays vital role in bank's effective performance. In order to sustain in today's competitive banking world banks must adopt advance tools, techniques and systems of communication. However the ways COVID-19 has heavily impacted in the business, due to which managers' face a lot of pressure and unable to make accurate decision. Similarly, this section also deals with minimizing communication barriers and remedial measures for managerial communication improvement at present context in Nepalese market. managers were also asked what can be the strategy that bank can adopt which can increase efficiency and effectiveness of banking communicating that can help to smooth the relation within the organization through better delivery of services.

Brining clarity while giving speech or talking can be considered as widely used communication strategy in banks as $69.13 \%$ respondents portrayed it is the management strategy being widely used by banks, regularly gather feedback for improvement is one of the used strategy in banks as $16.54 \%$ respondents portrayed as management strategy for managerial communication and the least used system for communication was found to be providing communication training which was $1.9 \%$. Therefore there were other management strategies of regularly gather feedback for improvement which are practiced minimum $16.54 \%$ by managers as management strategy for managerial communication. Bank needs to gather different kinds of information so that they remain updated, secured regarding activities of their respective banks. While collecting information from the managers, $65.18 \%$ responded that branch manager are responsible for managerial communication whereas $24.69 \%$ told managerial staffs or employees are the responsible as they must provide information documents on time and $10.12 \%$ replied 
that head office highly is responsible for managerial communication as, it is the major source from where managers receives the message about the activities of banks (Figure 3).

Figure 3: Management Strategy that can be Adapted

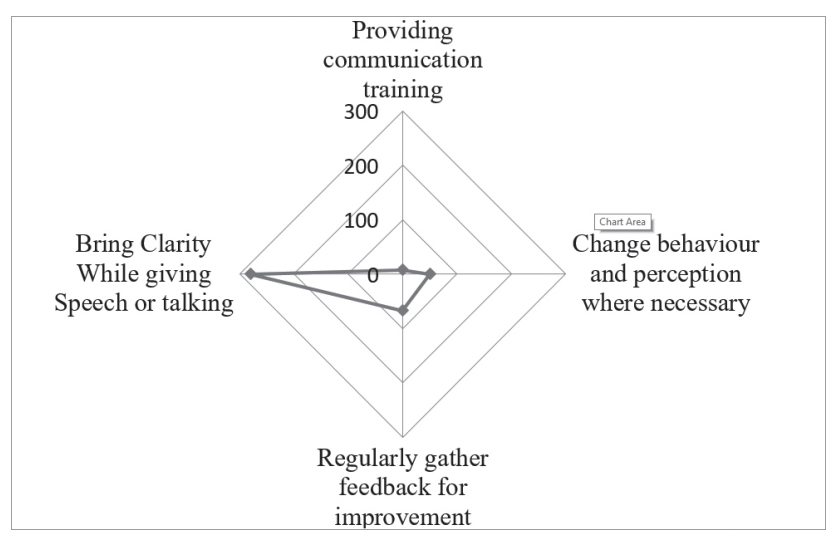

Lunenburg (2010) in the study claimed that noise is serious barrier in effective communication as when data is large, information is overloaded to a certain point that managers may not interpret conveniently and understand the message. Likewise, communication is easier in short distance as more communication channels are available and less technology is required (Lunenburg, 2011). As depicted from the study it can be said that $33.82 \%$ managers responded there is communication barrier in their respective organization sector whereas $66.17 \%$ managers answered there is no communication barrier in their respective organization.

\subsection{Solution to Minimize Communication Barriers}

Ademi (2016) mentioned that successful communication is necessary to develop a climate of trust and good communication facilitates the task of developing relevant and appropriate information systems. Similarly, communication is easier in short distances as more communication channels are available and less technology is required (Lunenburg, 2011). As per the result generated from the study $66.17 \%$ managers have not faced any kind's communication barrier but $33.82 \%$ have stated that there is communication barrier in their respective organization and they have provided solution by working on which banks can minimize the problem faced while communicating and making decision.

61.9\% participants unfolded that in order to minimize communication barrier in bank being a good listener could act and help bank accordingly which would save time of managers as well as employees or clients. Similarly, $19.5 \%$ answered use of simple and clear language is the solution to minimize communication barriers in an organization (Figure 4). Likewise, 10.12\% responded if remain aware of cultural differences then that would lead in solution to minimize communication barrier. Beside these reduction and elimination of noise can be taken in to consideration for minimizing communication barriers as said by $8.39 \%$ managers. 
Figure 4: Solution to Minimize Communication Barriers

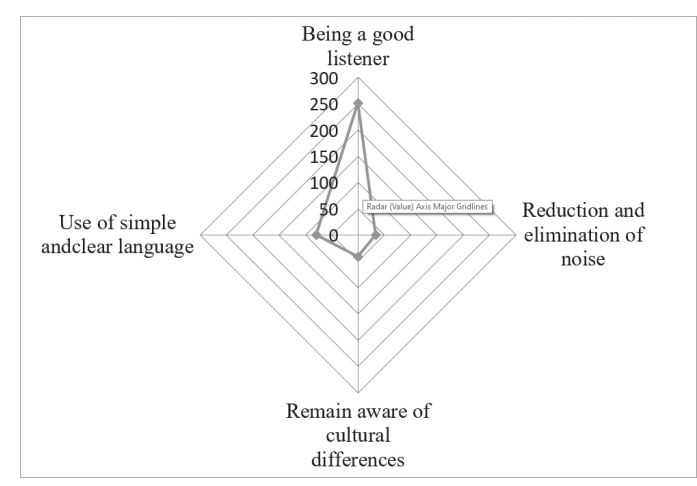

\section{Conclusion}

Efficient managerial level is crucial for organizational well-functioning and betterment, but more importantly communication plays vital role to build good relationship among managers to their subordinates. Being client service-related sector, banks need to perform more communication in order to perform their day-to-day transaction and dealing with the client and customers. Proper communication in banks further helps to assist employees, creating sense of mutual respect and favorable working environment. Earlier studies of Ahmed et al. (2010) revealed that ineffective communication would develop negative relation among employees and managers in banks. However, in Nepalese banking context, it is still unclear how to promote effective managerial communication and what are the barriers for doing so. Thus, this study aims to identify strategy for promoting effective managerial communication on banking sector in Kathmandu valley. In order to conduct the study, we follow descriptive cross-sectional research design and interrogate 405 managers (383 branch managers and 22 operating managers) of Nepalese commercial Banks in Kathmandu Valley. We follow structured questionnaire survey using KOBO Toolbox. The study prepared Managerial communication index to identify the communication skills of managers on banking communication and in decision making.

Our study revealed that managers of banking sector in Kathmandu valley are highly aware of managerial communication in terms of identity factors, negotiation and adaptation, and decision making. However, $57.77 \%$ managers felt challenges in communication process. They opined such challenges should be identified according to circumstance and proper strategy that can cope with the problem must be adopted. Further, $61.9 \%$ managers perceived that to minimize barriers in communication they must be good listener. Managers also suggest that brining clarity while giving speech or talking (69.13\%), regularly gather feedback for improvement $(16.54 \%)$ and change behavior and perception when necessary (12.34\%) are some management strategies identified for promoting effective managerial communication. Based on the findings, the study concludes that information must be properly disseminated to its stakeholders by bank managers which will help to convey message effectively leading clarity in the work and enhanced productivity. After assessing the objectives, analyzing the results and the knowledge assimilated from this study following recommendations are kept forward (i) banking managers should 
start prioritizing in improving their listening skills (ii) they should use if simple and clear language while communicating, and (iii) they must provide adequate time to employees within the workplace.

One important issue that came up is current study is directed on managerial communication in decision making of banking sector. As both traditional and modern means of communication are being practiced by today's banks in Nepal, it is still unknown whether managers prefer and understand traditional or modern ways of communication and how the blend of both ways of communication can help them. The issue requires further investigation as to find out best way of communication that banks can practice in order to satisfy and aware their employees about communication techniques and decision making being practice by banks to facilitate them.

\section{Reference}

Ademi, N. (2016). The concept and the ways of managerial communication. International Journal of Economics \& Management Sciences, 05(06).

Adhikari, D. B., Shakya, B., Devkota, N., Karki, D., Bhandari, U., Parajuli, S., \& Paudel, U. R. (2021). Financial hurdles in small business enterprises in Kathmandu Valley. Modern Economy, 12(6), 1105-1118.

Ahmed, Z., Shields, F., White, R., \& Wilbert, J. (2010). Managerial communication: The link between frontline leadership and organizational performance. In First Annual General Business Conference Conference Proceedings (p. 69).

Al Nahyan, M. T., Sohal, A., Hawas, Y., \& Fildes, B. (2019). Communication, coordination, decision-making and knowledge-sharing: a case study in construction management. Journal of Knowledge Management, 23(9), 1764-1781.

Bel, R., Smirnov, V., \& Wait, A. (2018). Managing change: Communication, managerial style and change in organizations. Economic Modelling, 69, 1-12.

Chong, E. (2013). Managerial competencies and career advancement: A comparative study of managers in two countries. Journal of Business Research, 66(3), 345-353. https://doi.org/10.1016/j.jbusres.2011.08.015

Chung, H. F. L., Wang, C. L., Huang, P. H., \& Yang, Z. (2016). Organizational capabilities and business performance: When and how does the dark side of managerial ties matter? Industrial Marketing Management, 55, 70-82. https://doi.org/10.1016/j.indmarman.2016.02.014

Dane, E., \& Pratt, M. G. (2007). Exploring intuition and its role in managerial decision making. Academy of management review, 32(1), 33-54.

Dasgupta, S. A., Suar, D., \& Singh, S. (2013). Impact of managerial communication styles on employees' attitudes and behaviours. Employee Relations, 35(2), 173-199. https://doi. org/10.1108/01425451311287862 
Ekeowa Kelvin-Iloafu, L. (2016). The role of effective communication in strategic management of organizations. International Journal of Humanities and Social Science, 6(12), 93-99.

Genç, R. (2017). The importance of communication in sustainability \& sustainable strategies. Procedia Manufacturing, 8, 511-516.

Hoeven, C. L., Miller, V. D., Peper, B., \& den Dulk, L. (2017). The work must go on: The role of employee and managerial communication in the use of work-life policies. Management Communication Quarterly, 31(2), 194-229. https://doi.org/10.1177/0893318916684980

Ishtiaque, A., Shrestha, M., \& Chhetri, N. (2017). Rapid urban growth in the Kathmandu valley, Nepal: Monitoring land use land cover dynamics of a himalayan city with landsat imageries. Environments, 4(4), 72. https://doi.org/10.3390/environments4040072

Kurtuhuz, A. M., Vasilescu, I., Lupu, F., Lupu, A. G., Radu, D. L., \& Kurtuhuz, M. C. (2011). The manager role in decision making. Annals of DAAAM and Proceedings of the International DAAAM Symposium, 22(1), 625-626.

Lunenburg, F. C. (2010). Communication : The process, barriers , and improving effectiveness. Schooling, $1,1-11$.

Lunenburg, F. C. (2011). Network patterns and analysis : Underused sources to improve communication effectiveness. National Forum Educational Administration and Supervision Journal, 28(4), 1-7.

Martovoy, A., \& Dos Santos, J. (2012). Co-creation and co-profiting in financial services. International Journal of Entrepreneurship and Innovation Management 1, 16(1-2), 114-135.

Mayfield, M., \& Mayfield, J. (2016). The effects of leader motivating language use on employee decision making. International Journal of Business Communication, 53(4), 465-484. https://doi. org/10.1177/2329488415572787

Mercado, S. A. (2000). Pre-managerial business education: A role for role-plays? Journal of Further and Higher Education, 24(1), 117-126. https://doi.org/10.1080/030987700112363

Mesaros, P., Mandicak, T., Mesarosova, A., \& Behun, M. (2016). Developing managerial and digital competencies trough BIM technologies in construction industry. ICETA 2016 - 14th IEEE International Conference on Emerging ELearning Technologies and Applications, Proceedings, 217-222. https://doi.org/10.1109/ICETA.2016.7802095

Mohanty, A. (1970). State of environment in Kathmandu Valley, Nepal: A special review. Journal of the Institute of Engineering, 8(1-2), 126-137. https://doi.org/10.3126/jie.v8i1-2.5103

Nabi, N. M., Foysol, K. M., \& Adnan, S. M. (2017). The role and impact of business communication on employee performances and job satisfactions: A case study on Karmasangsthan Bank Limited, Bangladesh. Arabian Journal of Business and Management Review, 7(3), 1-8. https://doi. org/10.4172/2223-5833.1000301 
NRB. (2018). List of Banks and Financial Institutions. Retrieved from ttps://www.nrb.org.np/contents/ uploads/2019/12/List-of-BFIs_July2018.pdf

Pant, P. R., \& Dongol, D. (2009). Kathmandu Valley profile: Briefing paper. Dongol, Devendra, (February).

Panth, A., \& Kafle, P. (2018). Maternal satisfaction on delivery service among postnatal mothers in a government hospital, Mid-Western Nepal. Obstetrics and gynecology international, 2018.

Parajuli, S., Paudel, U. R., \& Devkota, N. (2020). Banking communications: A perceptual study of customer relations. South Asian Journal of Social Studies and Economics, 23-34.

Paudel, U. R., Devkota, N., Ghale, B. A., \& Adhikari, K. (2018). Communication and gender in bachelor's degree students' adjustment process: A study in Kathmandu, Nepal. Journal of Education, Society and Behavioural Science, 1-9.

Paudel, U. R., Parajuli, S., Devkota, N., \& Mahapatra, S. K. (2020). What determines customers' perception of banking communication? An empirical evidence from commercial banks of Nepal. Global Economy Journal, 2050019.

Pokhrel, P. R. (2007). Challenges to effective public affairs communication. Socio-Economic Development Panorama, 1(2), 93-99.

Prasad, A. (2002). The contest over meaning: Hermeneutics as an interpretive methodology for understanding texts. Organizational research methods, 5(1), 12-33.

Rijal, S. (2007). Application of Management Control System in Nepalese Commercial Banks. Journal of Nepalese Business Studies, 3(1), 92-99. https://doi.org/10.3126/jnbs.v3i1.486

Roy, S. (2018). Corporate communications: global scenario. (June), 1-14.

Sapkota, N., Paudel, N., Bhattarai, R., \& Shrestha, R. (2018). Role of information communication technology ( ICT ) in Nepalese banking industry. American Scientific Research Journal for Engineering, Technology, and Sciences, 42(1), 15.

Shrestha, E., Devkota, N., Paudel, U. R., \& Parajuli, S. (2021). Post-merger Employee Satisfaction in Commercial Banks of Nepal: Findings from Employee Satisfaction Index. Journal of Business and Social Sciences Research, 6(1), 45-62.

Shrestha, S., Devkota, N., Paudel, U., Bhandari, U., \& Parajuli, S. (2020). Bankers' communication knowhow: An analysis from commercial banks of Kathmandu valley. Quest Journal of Management and Social Sciences, 2(1), 80-99.

Shrestha, S., Parajuli, S., \& Paudel, U. (2019). Communication in banking sector: A systematic review. Quest Journal of Management and Social Sciences, 1(2), 272-284.

Vilkinas, T., \& Cartan, G. (1997). How different are the roles displayed by female and male managers? Women in Management Review, 12(4), 129-135. 